\title{
Deposition of titanium based coatings by reactive detonation spraying
}

\section{Depozice povlaku na bázi titanu reaktivním detonačním nástřikem}

\author{
Panin S. ${ }^{1,3}$, Vlasov I. ${ }^{1,3}$, Dudina D. ${ }^{2}$, Ulyanitsky $V .^{2}$, Stankevich $R .{ }^{3}$, Batraev $I^{2}{ }^{2}$, Maruschak.$^{4}{ }^{4}$, Landová M. ${ }^{5}$ \\ ${ }^{1}$ Institute of Strength Physics and Materials Science SB RAS, Tomsk, Russia \\ ${ }^{2}$ Lavrentiev Institute of Hydrodynamics SB RAS, Novosibirsk, Russia \\ ${ }^{3}$ National Research Tomsk Polytechnic University, Tomsk, Russia \\ 4 Ternopil Ivan Pul'uj National Technical University, Ternopil, Ukraine \\ 5 Technical University of Košice, Department of Technology and Materials, Košice, Slovakia \\ E-mail: Maruschak.tu.edu@gmail.com
}

The structure and mechanical properties of the coatings formed by reactive detonation spraying of titanium in a wide range of spraying conditions were studied. The variable deposition parameters were the nature of the carrier gas, the spraying distance, the $\mathrm{O}_{2} / \mathrm{C}_{2} \mathrm{H}_{2}$ ratio, and the volume of the explosive mixture. The phase composition of the coatings and the influence of the spraying parameters on the mechanical properties of the coatings were investigated. In addition, nanohardness of the individual phases contained the coatings was evaluated. It was found that the composition of the strengthening phases in the coatings depends on the $\mathrm{O}_{2} / \mathrm{C}_{2} \mathrm{H}_{2}$ ratio and the nature of the carrier gas. Detonation spraying conditions ensuring the formation of composite coatings with a set of improved mechanical properties are discussed.

\section{INTRODUCTION}

At present, several coating deposition methods are known and widely used in the industry [1]. The choice of a particular method is dictated by a combination of factors, such as the level of loading and operating conditions, the shape, size and geometry of machine parts to be coated, the required thickness of the coating, the necessity for mechanical post-processing, the requirements for adhesive and cohesive strength and the cost of the final product.

Thermal spraying is widely used for surface strengthening and restoration. The variations of thermal spraying are plasma spraying, flame spraying, highvelocity oxy-fuel spraying (HVOF), cold gas-dynamic spraying and detonation spraying. Thermal spraying is used to deposit high-strength materials [2] and multicomponent coatings reinforced with finely dispersed inclusions, which ensure high coating performance $[3,4]$.
V př́spěvku jsou studovány struktura a mechanické vlastnosti povlakủ pripravených reaktivním nástřikem titanu za široké škály aplikačnich parametrů. Těmi byly zejména složeni nosného plynu, vzdálenost trysky, poměr kyslíku a acetylénu, a objem směsi. Bylo sledováno fázové složeni povlaku a vliv jmenovaných parametrů a nanotvrdost jednotlivých fází. Prritomnost vyztužujicich fázi závisi hlavně na pomèru kyslik/acetylén a složeni směsi nosného plynu. Tato metoda žárového nástřiku poskytuje kompozitni povlak se zlepšenými mechanickými vlastnostmi.

In order to form coatings containing intermetallic phases with high adhesion strength and corrosion resistance, vacuum spraying $[2,3,5]$ is employed or deposition is carried out in an inert gas atmosphere [6].

The sprayed metallic particles can chemically react with gases contained in the spraying atmosphere, which leads to the formation of finely dispersed ceramic phases in the coatings $[5,7,8]$.

A widespread technique of producing dispersionstrengthened coatings is the formation of oxide inclusions in metal matrices. This is achieved through oxidation of the molten particles when spraying is carried out in air. In this case, atmospheric plasma spraying can be efficiently employed [9]. A substantial drawback of this method is the porosity of the coatings and the nonuniformity of their structure.

One of the efficient technologies for restoration, repair and strengthening of machine parts is cold gas-dynamic spraying $[10,11]$. It is based on the layer-by-layer 
formation of coatings at supersonic flow velocities of the carrier gas and is associated with minimal heating of the sprayed material. The cohesive strength is, therefore, provided thanks to a high kinetic energy of the particles upon impact. This substantially reduces the probability of oxidation and eliminates the need for dynamic vacuum or an inert gas atmosphere. By selecting the optimal gas flow rate and the temperature of the gas, multicomponent coatings with a set of required physical and mechanical properties can be fabricated [11].

Currently, detonation spraying and HVOF are the most efficient methods of depositing coatings that can protect machine parts from erosion, corrosion and different types of wear $[12,13]$. Low porosity of the coatings is achieved due to high velocities of the particles [6]. The method can also be applied for metallization of ceramics and periodic restoration of the worn machine parts [14-16].

In this paper, the structure and mechanical properties of deposits formed on titanium substrates by reactive detonation spraying of a titanium powder were investigated. The aim of the present work was to determine the effect of the coating structure on the mechanical properties of the coatings.

\section{MATERIALS AND METHODS}

The deposition of the coatings onto titanium substrates was carried out using a computer controlled detonation spraying (CCDS2000) facility [17]. Titanium (99 \% purity, average particle size $15 \mu \mathrm{m}$, "PTOM-2", Russia) was used as a feedstock powder. Air or nitrogen was used as a carrier gas. Spraying was performed using different compositions of acetylene-oxygen mixtures corresponding to $\mathrm{O}_{2} / \mathrm{C}_{2} \mathrm{H}_{2}$ molar ratios of $0.7,1.1$, and 2.5 (Tab. 1). Conditions of the enhanced nitride formation were created by introducing nitrogen into the explosive mixture.

Microhardness of the coatings $H_{\mu}$ was measured with the use of a PMT-3 testing machine. The direction of indentation was cross-section to the substrate/coating interface. The load onto the Vickers pyramid was $100 \mathrm{~g}$. Elemental microanalysis of the coatings was carried out by Energy Dispersive Spectroscopy (EDS) using an INCA unit (Oxford, Instruments) attached to a LEO EVO 50 scanning electron microscope (Zeiss, Germany). In order to study the correlation between the structure and the mechanical properties of the coatings, three-point bending tests were carried out using an electromechanical testing machine Instron 5582. This loading scheme was chosen as under applied external force, the surface layer (the detonation coating) plays a major role in providing resistance to deformation and fracture. The threepoint bending tests in combination with photographing the specimen lateral surface allow gaining detailed information on the deformation behavior and estimating the cracking stress $\sigma_{c r}$. [18]. The stress under three-point bending was calculated with the help of equation (1) [19]:

$$
\sigma_{c r}=\frac{M_{\max }}{W},
$$

where $M_{\max }$ is the largest value of bending moment (2) ( $P$ is bending load; $l$ is the distance between the supports (span).

$$
M_{\max }=\frac{P \times l}{4},
$$

where $W$ is the resistance momentum, which for rectangular-section specimens can be calculated by equation (3) ( $b$ is the width and $h$ is the gauge height of the specimens).

$$
W=\frac{b \times h^{2}}{6} .
$$

For mechanical testing, rectangular specimens $20 \times 10 \times 2.5 \mathrm{~mm}$ in size were prepared using electroerosion cutting. The span (the distance between the supports) was $19 \mathrm{~mm}$. Since the titanium substrates possess high ductility, it was nearly impossible to fracture the specimen using the selected loading scheme. For this reason, the evaluation of the mechanical properties was carried out at a bending deflection of $2.5 \mathrm{~mm}$.

Tab. 1. Parameters of spraying and coating thickness / Parametry nástřiku a tloušt ky povlaků

\begin{tabular}{|c|c|c|c|c|c|}
\hline $\begin{array}{c}\text { Spraying } \\
\text { regime }\end{array}$ & $\begin{array}{c}\text { Composition of explosive } \\
\text { mixture, } \mathbf{O}_{\mathbf{2}} / \mathbf{C}_{\mathbf{2}} \mathbf{H}_{\mathbf{2}}\end{array}$ & $\begin{array}{c}\text { Spraying distance } \\
{[\mathbf{m m}]}\end{array}$ & $\begin{array}{c}\text { Explosive } \\
\text { charge [\%] }\end{array}$ & Carrier gas & $\begin{array}{c}\text { Coating thickness }\left(\mathbf{h}_{\mathbf{n}}\right) \\
{[\boldsymbol{\mu m}]}\end{array}$ \\
\hline 1 & 1.1 & 100 & 30 & air & 270 \\
\hline 2 & 2.5 & 100 & 30 & air & 275 \\
\hline 3 & 1.1 & 10 & 40 & nitrogen & 160 \\
\hline 4 & 0.7 & 10 & 40 & nitrogen & 291 \\
\hline 5 & 0.7 & 10 & 50 & nitrogen & 190 \\
\hline 6 & 0.7 & 100 & 50 & nitrogen & 750 \\
\hline 7 & $1.1+33 \% \mathrm{~N} 2$ & 10 & 60 & nitrogen & 235 \\
\hline 8 & $1.1+33 \% \mathrm{~N} 2$ & 100 & 60 & nitrogen & 285 \\
\hline
\end{tabular}


Scratch tests were carried out to evaluate the friction coefficient. A Revetest-RST scratcher (CSM-Instruments, Switzerland) was used for these measurements. The velocity of the indenter was $2 \mathrm{~mm} / \mathrm{min}$. The load was increased from 0.6 to $200 \mathrm{~N}$. The friction coefficient was calculated as an average over the entire scratch length.

\section{RESULTS AND DISCUSSION}

\section{Spraying regime No. 1 and No. 2}

For the given pair of specimens the spraying distance $(100 \mathrm{~mm})$, filling of the barrel $(30 \%)$, and the carrier gas (air) were the same. They differed by the explosive mixture ratio $\mathrm{O}_{2} / \mathrm{C}_{2} \mathrm{H}_{2}$ only (Table 1 .). The analysis of the SEM images (Fig. 1a,b) shows that the coating consists of a set of densely packed splats, which is typical of coatings obtained by thermal spraying.

SEM and EDS data of coating No. 1 allow detecting titanium and its oxides. The formation of oxynitrides was confirmed by EDS; however, due to overlapping of titanium and nitrogen peaks in the EDS, the quantitative analysis is difficult to conduct. In our previous study [8] the detonation spraying of Ti powder with the use of similar deposition modes was carried out. By means of the XRD the formation of $\mathrm{TiN}_{\mathrm{x}} \mathrm{O}_{\mathrm{y}}, \mathrm{TiO}, \mathrm{Ti}_{2} \mathrm{O}_{3}$ phases have been detected. To the authors opinion the same phases should be formed in the coatings studied in this paper. The formation of the oxynitrides is related to the presence of nitrogen in the air (carrier gas). Metallic titanium in the micrographs is seen as bright regions against the background of a darker matrix of titanium oxides/oxynitrides. The oxygen content in such regions is $\sim 35 \%$.

So, detonation spraying under the selected regime allows depositing a coating with a composite structure consisting of titanium and its oxides. The coating shows a low porosity and a uniform microstructure, which can be attributed to a uniform phase distribution over the entire coating volume (Fig. 1a,b). Coating No. 2 has a similar structure; however, a larger number of

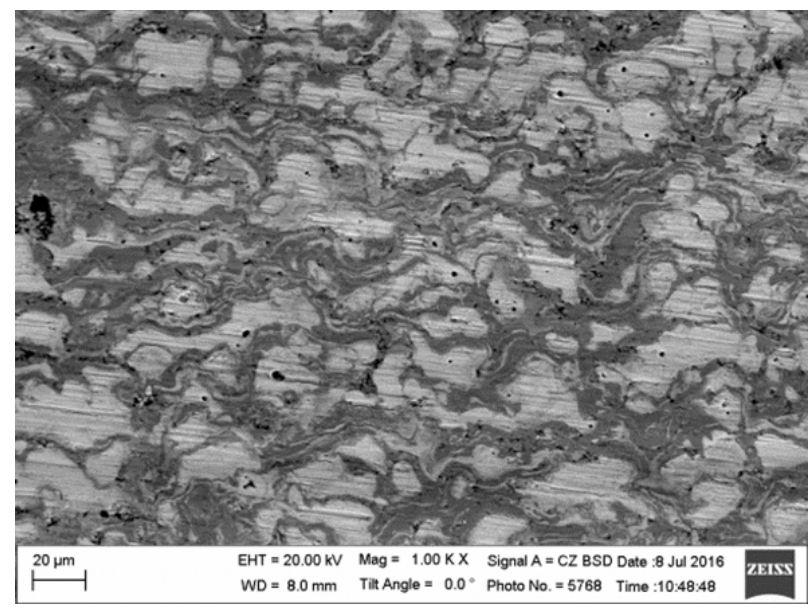

a) No. 1

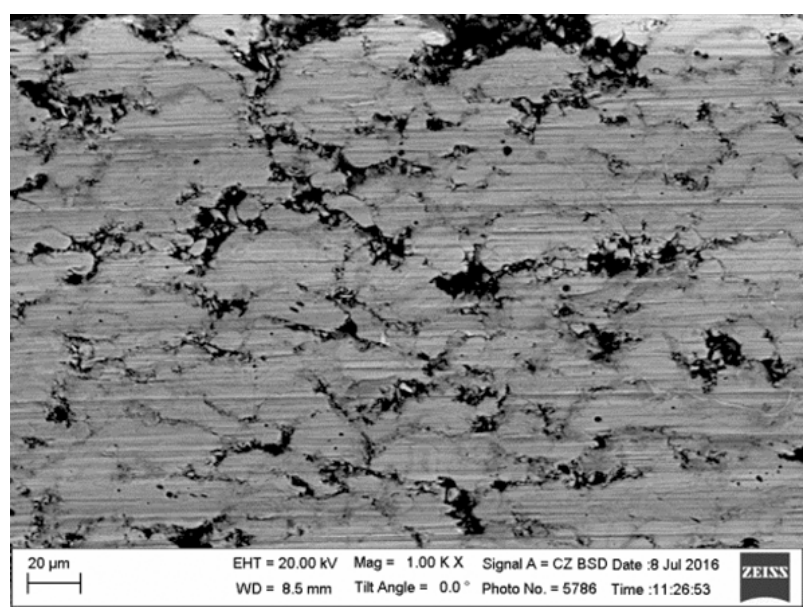

c) No. 3

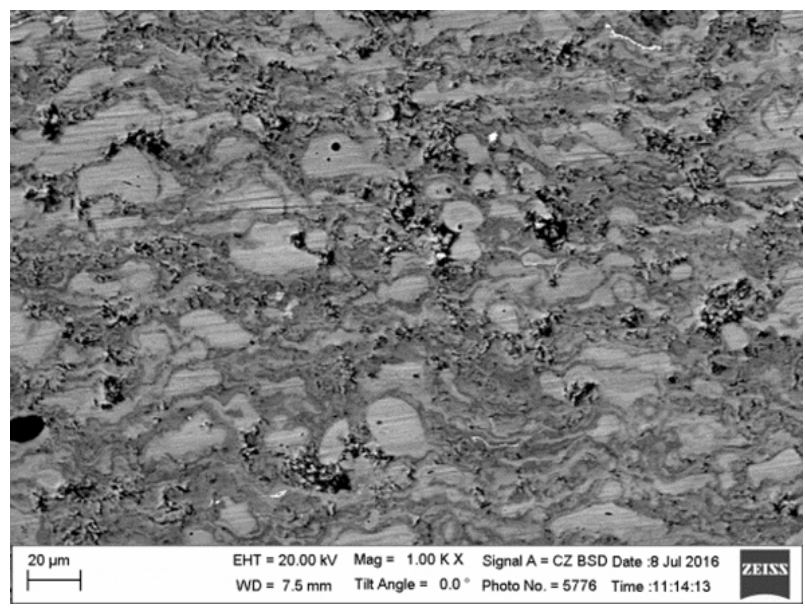

b) No. 2

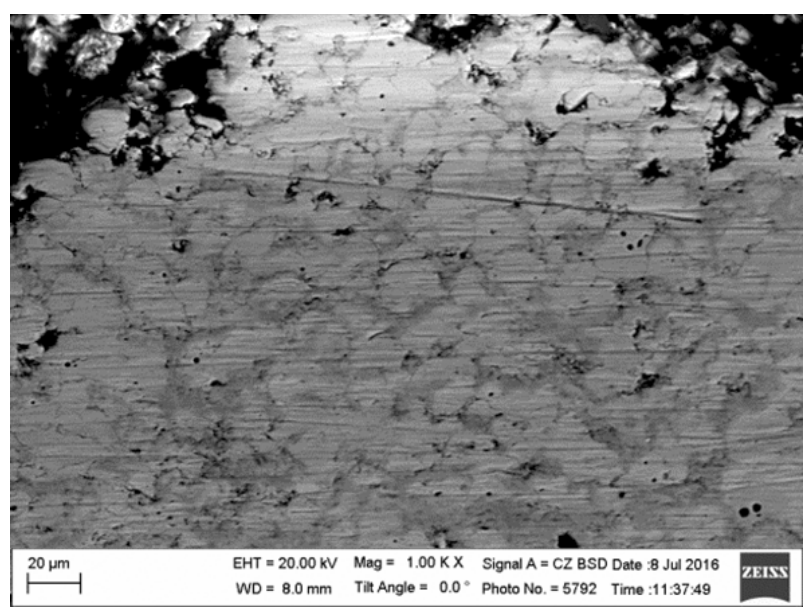

d) No. 4

Fig. 1. SEM-micrographs of the cross section for the specimens No. $1-4$ (continue on next page) Obr. 1. SEM snímky řezů vzorků č. 1 - 4 (pokračování na další straně) 


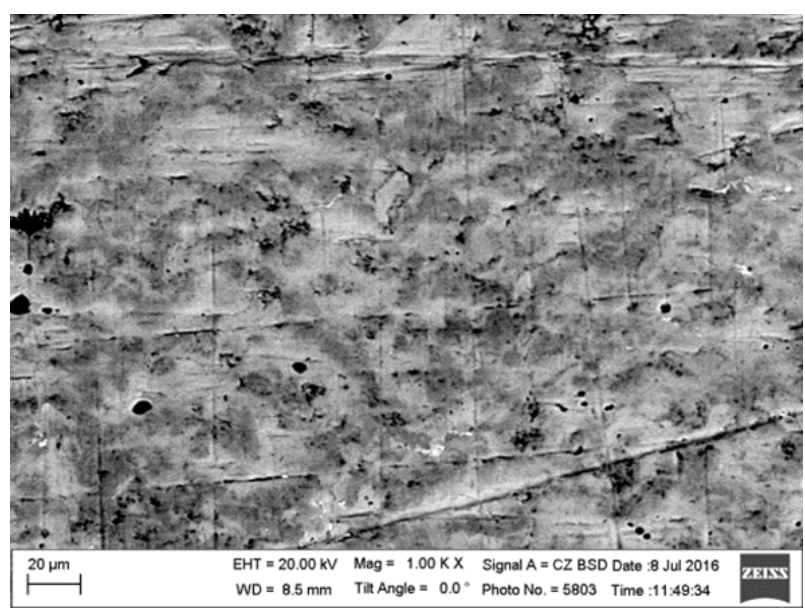

e) No. 5

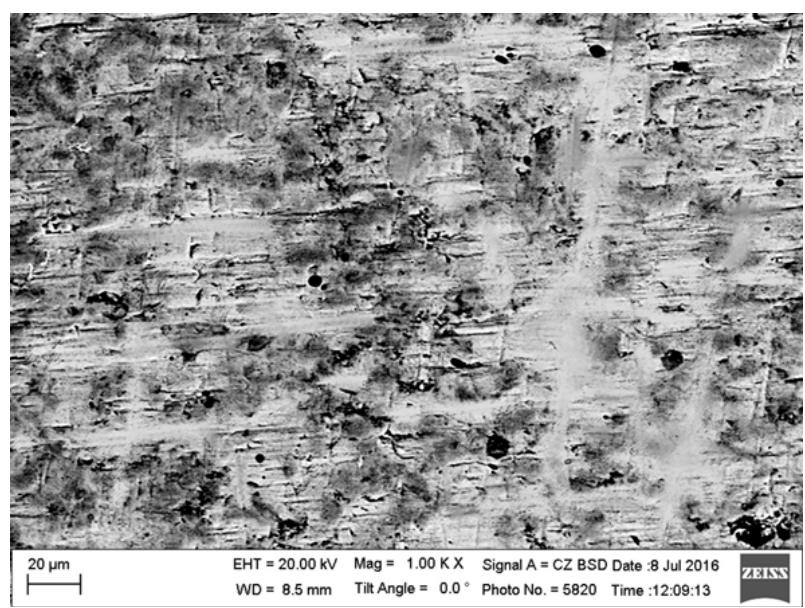

g) No. 7

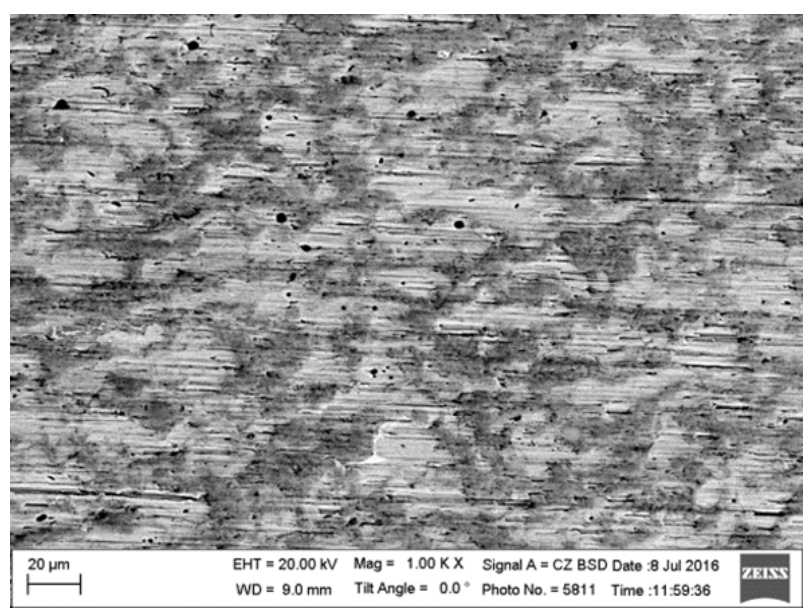

f) No. 6

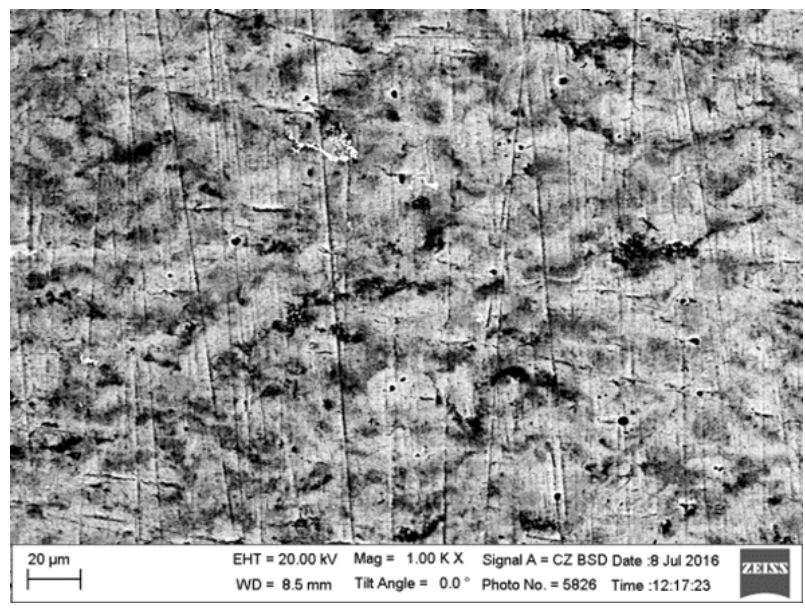

h) No. 8

Fig. 1. SEM-micrographs of the cross section for the specimens No. $5-8$

Obr. 1. SEM snímky řezů vzorků č. $5-8$

splat-shaped inclusions of smaller sizes are observed. A noticeable number of micropores of round shape are a characteristic feature of the coating. The oxygen content in the oxide-rich regions is about $45 \%$, which is higher than in specimen No. 1 (Fig. 1, Table 2.). In the regions consisting mostly of metallic titanium, the presence of oxygen is also detected (less than $8 \%$ ).

\section{Spraying regime No. 3 and No. 4}

For this pair of coatings the $\mathrm{O}_{2} / \mathrm{C}_{2} \mathrm{H}_{2}$ ratio was equal to 1.1 and 0.7 (for the specimens No. 3 and No. 4 , respectively). However, the spraying distance was additionally reduced (it made $10 \mathrm{~mm}$ ) but the carrier gas was replaced by the nitrogen (Tab. 1).

A reduction in the oxygen content in the explosive mixture should result in a decrease in the content of the oxides in the coating. The use of nitrogen as a carrier gas can lead the formation of nitrides.

From the SEM micrographs of the specimen's cross section (Fig. 1c,d), it can be seen that during the grinding/polishing process some particles detached from the surface. This indicates a reduced cohesive strength in comparison with specimens No. 1 and 2. It is also clear that titanium particles after detonation spraying have retained a predominantly globular shape (their impact energy during spraying was not high). This result is most likely related to a substantial decrease in the spraying distance. A higher oxygen amount in the explosive mixture results in the formation of a coating with a higher strength. As is seen from the Fig. 1c,d, a greater number of dark regions are observed in coating No. 4, which correspond to titanium carbonitrides.

A high porosity is a characteristic feature of specimen No. 3 (Fig. 1c). Thin layers are located along the boundaries of the titanium particles. The oxygen content in these layers does not exceed $15 \%$ (Tab. 2), which is significantly lower than the oxygen content in specimens No. 1 and No. 2. In large pores of the coating, a higher content of carbon is detected than in small pores (up to $35 \%$ ). 
Coating No. 4 is denser than coating No. 3. A higher content of $\mathrm{C}_{2} \mathrm{H}_{2}$ in the explosive mixture has led to an increase in the carbon content in the coating, as is evidenced from the EDS data (Tab. 2.). The carbon content along the titanium particle boundaries is $\sim 25 \%$, reaching $45 \%$ in large pores.

\section{Spraying regime No. 5 and No. 6}

For specimens No. 5 and No. 6, the spraying distance was 10 and $100 \mathrm{~mm}$, respectively. According to the SEM data, these coatings have a fine-grained structure (Fig. 1e,f), in which titanium particles are surrounded by ceramic grains.

According to the EDS of specimen No. 5, the oxygen content outside of unreacted titanium particles phases does not exceed $10 \%$, while the content of carbon is about $20 \%$. In the similar regions of the microstructure of specimen No. 6 , the oxygen content is about $15 \%$, while the carbon content is $25 \%$ (Fig. 1e, Tab. 2). It can be assumed that when a longer spraying distance is used, a greater transformation degree of titanium is achieved. Therefore, the interphase boundaries appear more distinct, while the oxygen and carbon contents in specimen No. 6 are higher (Fig. 1f). Using a shorter spraying distance, a coating with increased values of microhardness was obtained (specimen No. 5, Tab. 2).

\section{Spraying regime No. 7 and No. 8}

The spraying distance was $10 \mathrm{~mm}$ for specimen No. 7 while it was $100 \mathrm{~mm}$ for specimen No. 8 . Additionally, nitrogen was added to the $\mathrm{O}_{2} / \mathrm{C}_{2} \mathrm{H}_{2}$ mixture in an amount of $33 \%$ by volume. It was assumed that the introduction of nitrogen into the explosive mixture would favor the formation nitrides in the coatings [8]. As is seen from Fig. 1g,h, the coating structure is rather uniform and is represented by metallic titanium and ceramic phases. A number of small microcracks and round pores can be observed. An increase in the spraying distance for specimen No. 8 has led to the formation of pronounced interphase boundaries due to a higher chemical transformation degree of titanium. The EDS data for specimen No. 7 show that the carbon content in the coating is less than $6 \%$, while the oxygen content is about $30 \%$ (Tab. 2).

In specimen No. 8 , the oxygen content was lower (15\%), while the content of carbon did not change substantially. This can be the reason for a decrease in the microhardness. In both specimens, titanium nitrides were found to dominate in the dark regions.

\section{Three-point bending test}

The results of three-point bending tests (Fig. 2a, Tab. 2) show that the value of the $\sigma_{2.5}$ parameter in

Tab. 2. Mechanical properties of the specimens / Mechanické vlastnosti vzorki

\begin{tabular}{|c|c|c|c|c|c|c|}
\hline No. & $\begin{array}{l}\text { Characteristic } \\
\text { regions at the } \\
\text { cross-section }\end{array}$ & $\begin{array}{l}\text { Chemical composition according } \\
\text { to data of microanalysis } \\
\text { [at. } \%]\end{array}$ & $\mathrm{H}_{\mu}[\mathrm{GPa}]$ & $\begin{array}{c}\text { Friction } \\
\text { coefficient } \mu_{0}\end{array}$ & $\sigma_{\mathrm{cr}}[\mathrm{MPa}]$ & $\sigma_{2,5}[\mathrm{MPa}]$ \\
\hline \multirow{2}{*}{1} & Bright areas & $\mathrm{Ti} \sim 99, \mathrm{O} \sim 1$ & \multirow{2}{*}{$3.70 \pm 0.03$} & \multirow{2}{*}{0.406} & \multirow{2}{*}{98.4} & \multirow{2}{*}{955} \\
\hline & Dark areas & $\mathrm{Ti} \sim 65, \mathrm{O} \sim 35$ & & & & \\
\hline \multirow{2}{*}{2} & Bright areas & $\mathrm{Ti} \sim 92, \mathrm{O} \sim 8$ & \multirow{2}{*}{$3.84 \pm 0.07$} & \multirow{2}{*}{0.412} & \multirow{2}{*}{140.5} & \multirow{2}{*}{850} \\
\hline & Dark areas & $\mathrm{Ti} \sim 55, \mathrm{O} \sim 45$ & & & & \\
\hline \multirow{2}{*}{3} & Bright areas & $\mathrm{Ti} \sim 94, \mathrm{O} \sim 6$ & \multirow{2}{*}{$2.68 \pm 0.07$} & \multirow{2}{*}{0.637} & \multirow{2}{*}{87.9} & \multirow{2}{*}{825} \\
\hline & Dark areas & $\mathrm{Ti} \sim 50, \mathrm{O} \sim 15, \mathrm{C} \sim 35$ & & & & \\
\hline \multirow{2}{*}{4} & Bright areas & $\mathrm{Ti} \sim 94, \mathrm{O} \sim 6$ & \multirow{2}{*}{$2.45 \pm 0.11$} & \multirow{2}{*}{0.661} & \multirow{2}{*}{44.9} & \multirow{2}{*}{1055} \\
\hline & Dark areas & $\mathrm{Ti} \sim 70, \mathrm{O} \sim 5, \mathrm{C} \sim 25$ & & & & \\
\hline \multirow{2}{*}{5} & Bright areas & $\mathrm{Ti} \sim 93, \mathrm{O} \sim 7$ & \multirow{2}{*}{$2.72 \pm 0.09$} & \multirow{2}{*}{0.580} & \multirow{2}{*}{94.2} & \multirow{2}{*}{945} \\
\hline & Dark areas & $\mathrm{Ti} \sim 70, \mathrm{O} \sim 10, \mathrm{C} \sim 20$ & & & & \\
\hline \multirow{2}{*}{6} & Bright areas & $\mathrm{Ti} \sim 97, \mathrm{O} \sim 3$ & \multirow{2}{*}{$2.02 \pm 0.01$} & \multirow{2}{*}{0.594} & \multirow{2}{*}{10} & \multirow{2}{*}{870} \\
\hline & Dark areas & $\mathrm{Ti} \sim 60, \mathrm{O} \sim 15, \mathrm{C} \sim 25$ & & & & \\
\hline \multirow{2}{*}{7} & Bright areas & $\mathrm{Ti} \sim 95, \mathrm{O} \sim 5$ & \multirow{2}{*}{$2.74 \pm 0.09$} & \multirow{2}{*}{0.675} & \multirow{2}{*}{372.1} & \multirow{2}{*}{945} \\
\hline & Dark areas & $\mathrm{Ti} \sim 64, \mathrm{O} \sim 30, \mathrm{C} \sim 6$ & & & & \\
\hline \multirow{2}{*}{8} & Bright areas & $\mathrm{Ti} \sim 95, \mathrm{O} \sim 5$ & \multirow{2}{*}{$2.29 \pm 0.02$} & 0585 & 335 & 875 \\
\hline & Dark areas & $\mathrm{Ti} \sim 77, \mathrm{O} \sim 15, \mathrm{C} \sim 8$ & & 0.585 & 35.5 & $8 / 5$ \\
\hline
\end{tabular}


the specimens varies within a wide range $\left(\sigma_{25}=\right.$ $=820-1055 \mathrm{MPa})$. However, the value of this parameter weakly correlates with the strength characteristics of the coatings, partially due to significant differences in the coating thickness. It was concluded that the shape of the three-point bending diagram does not unambiguously show the contribution of the coating to the deformation resistance of the entire assembly. Thus, it is necessary to measure the mechanical properties of the coatings locally.

\section{Scratch tests}

With the help of scratch tests, a number of mechanical characteristics of the coatings were measured (Fig. 2b,c, Tab. 2). The value of the friction coefficient was determined. The obtained results correlate with the coating strength. The values of microhardness of specimens No. 1 and 2 are the highest among the studied

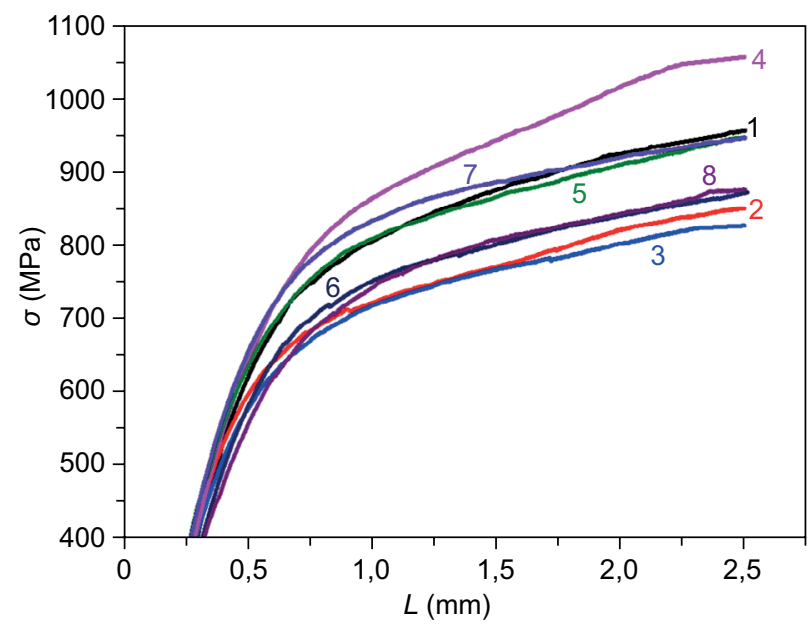

a)

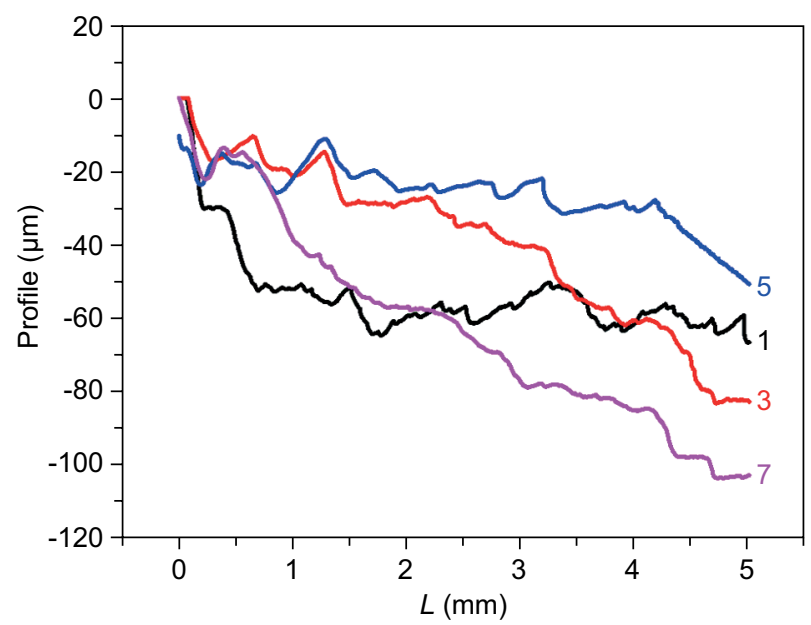

b) specimens $\left(H_{100}=3.7-3.84 \mathrm{GPa}\right)$, while the friction coefficients are the lowest $\left(\mu_{0} \sim 0.41\right)$.

Spraying regime 1 . During the scratch test, the indenter initially quickly penetrated into the coating at $55 \mu \mathrm{m}$, the track length reaching $1 \mathrm{~mm}$. Upon further scratching, the penetration depth increased to $67 \mu \mathrm{m}$. This was probably related to an imperfect structure of the surface layer. The scratch profile oscillated due to a nonuniform structure of the coating (Fig. 2b, curve 1). The coating possesses a sufficiently high bending cracking resistance $\left(\sigma_{\mathrm{cr}}=98.4 \mathrm{MPa}\right)$.

Spraying regime 2 . With increasing load, the penetration depth of the pyramid during the scratch test changed almost linearly (Fig. 2c, curve 2). At the end of the test, the indenter reached a depth of $63.4 \mu \mathrm{m}$, which is close to the value observed during testing of specimen No. 1. This agrees with a higher microhardness of specimen No. 2 as compared to specimen No. 1. The key mechanical characteristic of coating No. 2 is improved relative to those of coating No. 1: the fracture initiation stress is increased by $43 \%$ (Tab. 2). This change is associated with the formation of a high strength titanium oxide-based matrix.

Spraying regime 3 . The pattern of the scratching diagram is similar to that of specimen No. 2, while the indentation depth at the end of the profile is $83.3 \mu \mathrm{m}$ (Fig. 2b, curve 3). This correlates well with a decrease in the microhardness down to $2.68 \mathrm{GPa}$. However specimen No. 3 has a moderate value of the cracking stress.

Spraying regime 4 . The maximum indentation depth was $140.5 \mu \mathrm{m}$ (Fig. 2c, curve 4). Such a penetration depth of the indentor should be attributed to structural heterogeneity confirmed by the scratch profile at distances of 3-5 $\mathrm{mm}$ from the onset of scratching. The cracking stress is low.

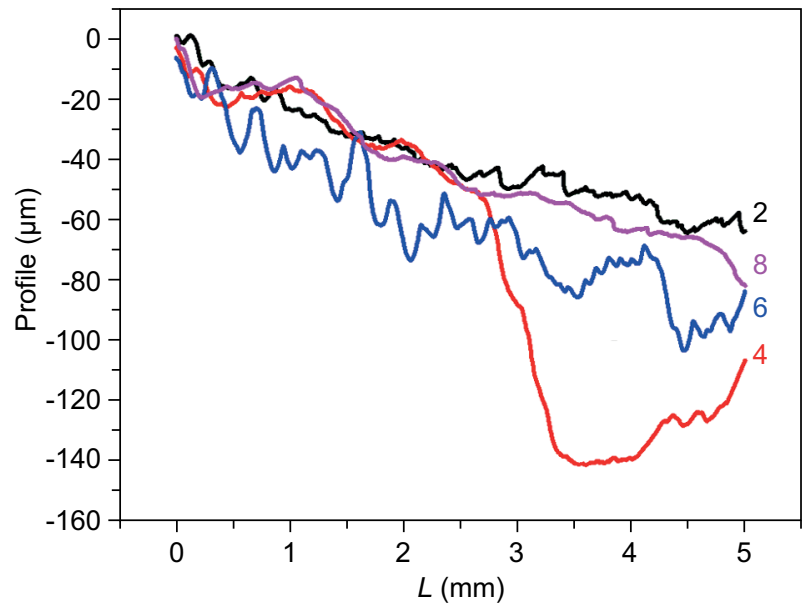

c)

Fig. 2. Three-point bending diagram for "coating - titanium substrate" composites (a); scratching diagrams of the coatings $(\mathrm{b}, \mathrm{c})$

Obr. 2. 3-bodový ohyb kompozitu „povlak-Ti substrát” (a); záznam scratch testu povlaků (b,c) 
Spraying regime 5. The indenter penetrated smoothly into the material without any significant jumps. The maximum penetration depth was $50.7 \mu \mathrm{m}$ (Fig. 2b, curve 5). The diagram shows several peaks and zones with different rates of indenter penetration, which indicate a heterogeneous structure of the coating. This correlates well with mechanical properties - high values of cracking stresses and microhardness.

Spraying regime 6. The maximum depth of the indenter penetration was $102.2 \mu \mathrm{m}$, while the indentation profile showed pronounced oscillation, which indicate a noticeable fraction of elastic recovery (Fig. 2c, curve 6). The depth of the track increased gradually with the applied load. At a scratching distance of $4 \mathrm{~mm}$, the oscillation frequency increased, which may be attributed to structural heterogeneity at the given depth. This coating possesses the lowest hardness.

The thickness of the coating in specimen No. 6 was 4 times greater than that in the rest of the specimens), which significantly affected the crack resistance measured during bending $\left(\sigma_{\mathrm{cr}}\right)$. Nevertheless, the bending cracking resistance of specimen No. 6 is lower than that of specimen No. 5 .

Spraying regime 7 . The profile of the scratching diagram was close to linear (without pronounced oscillations), while the maximum penetration depth at the end of the track was $103.5 \mu \mathrm{m}$ (Fig. 2b, curve 7). This specimen shows the maximum cracking stress among the studied compositions $\left(\sigma_{\mathrm{cr}}=372 \mathrm{MPa}\right)$.

Spraying regime 8 . In terms of the shape of the indentation diagram and parameters of the test, this composition is similar to specimen No. 7 (Fig. 2c, curve 8). However, the bending cracking stress is substantially lower $\left(\sigma_{\mathrm{cr}}=33 \mathrm{MPa}\right)$.

\section{CONCLUSION}

The structure and mechanical properties of the coatings deposited by reactive detonation spraying of a titanium powder were studied for three characteristic compositions of the explosive mixture and simultaneous variation of other deposition parameters. The composition of the individual phases of the coatings as well as the effect of the spraying regimes on the mechanical properties of the coatings was investigated. For the three characteristic modes of the coating formation (the composition of the explosive mixture and the carrier gas), the following recommendations were formulated.

Spraying with air as a carrier gas, no nitrogen added into the explosive mixture. An increase in the $\mathrm{O}_{2} / \mathrm{C}_{2} \mathrm{H}_{2}$ from 1.1 and 2.5 leads to an increase in the cracking resistance under three-point bending due to formation of a hierarchically organized coating structure with clearly exhibited phase boundaries. Deposition of titanium at $\mathrm{O}_{2} / \mathrm{C}_{2} \mathrm{H}_{2}=2.5$ allows obtaining coatings with a high microhardness and a low friction coefficient.

Spraying with nitrogen as a carrier gas, no nitrogen added into the explosive mixture. A short spraying distance $(10 \mathrm{~mm})$ and a low oxygen content in the explosive mixture $\left(\mathrm{O}_{2} / \mathrm{C}_{2} \mathrm{H}_{2}=0.7\right)$ makes it possible to form a heterogeneous structure of the coating. This ensures mechanical properties comparable to those of the coatings, in which the oxide phases were predominantly formed. The coatings show a moderate crack resistance, a high microhardness $\left(H_{100}=2.72 \mathrm{GPa}\right)$ and a high friction coefficient $\left(\mu_{0} \sim 0.58\right)$.

Spraying with nitrogen as a carrier gas and nitrogen added to the explosive mixture. The formation of a complex heterogeneous structure makes it possible to achieve a high crack resistance under three-point bending and a high microhardness $\left(H_{100}=2.74 \mathrm{GPa}\right)$. The friction coefficient of the coating was $\mu_{0} \sim 0.68$.

Based on the obtained results, the detonation spraying regimes used for specimens No. 2 and 7 are recommended for practical applications.

\section{Acknowledgement}

The work was performed with a partial support by Grant No. 11.2 of the Russian Academy of Sciences. The authors are grateful to "Nanotech" Shared Use Center of ISPMS SB RAS for the assistance in running fractographic investigations. The nanoindentation tests were carried out at Tomsk Polytechnic University within the framework of Tomsk Polytechnic University Competitiveness Enhancement Program grant.

\section{REFERENCES}

1. Nikitenkov N.N.: Modern Technologies for Creating the Thin-film Systems and Coatings, $1^{\text {st }}$ ed., InTech, London, 2017, DOI: $10.5772 / 63326$.

2. Deevi S.C., Sikka V.K. Application of reaction synthesis principles to thermal spray coatings, Journal of Materials Science, 1997, 32, 3315-3325.

3. Fauchais P., Montavon G., Lima R.S., Marple B.R. Engineering a new class of thermal spray nano-based microstructures from agglomerated nanostructured particles, suspensions and solutions: an invited review Journal of Physics D: Applied Physics, 2011, 44, 093001.

4. Kovaleva M., Tyurin Yu, Kolisnichenko O., Prozorova M., and Arseenko M. Properties of detonation nanostructured titanium-based coatings, Journal of Thermal Spray Technology, 2013, 22, 518-524.

5. Lidong Zhao, Erich Lugscheider Reactive plasma spraying of TiAl6V4 alloy, Wear, 2002, 253, 1214-1218.

6. Fauchais P., Montavon G., Bertrand G. From powders to thermally sprayed coatings, Journal of Thermal Spray Technology, 2010, 19, 56-80. 
7. Valente T., Galliano F.P. Corrosion resistance properties of reactive plasma-sprayed titanium composite coatings, Surface and Coatings Technology, 2000, 127, 86-92.

8. Ulianitsky V.Y., Dudina D.V., Batraev I.S., Kovalenko A.I., Bulina N.V., Bokhonov B.B. Detonation spraying of titanium and formation of coatings with spraying atmosphere-dependent phase composition, Surface and Coatings Technology, 2015, 261, 174-180.

9. Yao Y., Wang Z., Zhou Z., Jiang S., Shao J. Study on reactive atmospheric plasma-sprayed in situ titanium compound composite coating, Journal of Thermal Spray Technology, 2013, 22, 509-517.

10. Peat T., Gallowaya A., Toumpis A., McNutt P., Iqbal N. The erosion performance of cold spray deposited metal matrix composite coatings with subsequent friction stir processing, Applied Surface Science, 2017, 396, 1635-1648.

11. Klinkov S.V., Kosarev V.F., Sova A.A., Smurov I. Deposition of multicomponent coatings by cold spray, Surface and Coatings Technology, 2008, 202, 5858-5862.

12. Dongmo E., Wenzelburger M., Gadow R. Analysis and optimization of the hvof process by combined experimental and numerical approaches, Surface and Coatings Technology, 2008, 202, 4470-4478.
13. Smurov I., Ulianitsky V. Computer controlled detonation spraying, Surface Engineering, 2011, 27, 557-559.

14. Senderowski C., Chodala M., Bojar Z. Corrosion behavior of detonation gun sprayed Fe-Al type intermetallic coating, Materials, 2015, 8, 1108-1123.

15. Saladi S., Menghani J., Prakash S. Effect of $\mathrm{CeO}_{2}$ on cyclic hot-corrosion behavior of detonation-gun sprayed $\mathrm{Cr}_{3} \mathrm{C}_{2}-\mathrm{NiCr}$ coatings on Ni-based superalloy, Journal of Materials Engineering and Performance, 2015, 24, 1379-1389.

16. Senderowski C. Nanocomposite Fe-Al intermetallic coating obtained by gas detonation spraying of milled self-decomposing powder, Journal of Thermal Spray Technology, 2014, 23, 1124-1134.

17. Ulianitsky V., Shtertser A., Zlobin S. et al. Computercontrolled detonation spraying: from process fundamentals toward advanced, Journal of Thermal Spray Technology, 2011, 20, 791-801.

18. Isakov M., Matikainen V., Koivuluoto H., May M. Systematic analysis of coating-substrate interactions in the presence of flow localization, Surface and Coatings Technology, 2017, 324, 264-280.

19. Gere J.M., Goodno B.J. Mechanics of Materials, $8^{\text {th }}$ edition, Cengage Learning, Canada, 2012. 